\title{
Re-thinking professional development and accountability: towards a more educational training practice
}

DOI 10.1515/ijtr-2015-0002

received February 11, 2015; accepted May 20, 2015

\begin{abstract}
In this article, I discuss the contribution of theoretical resources to the transformation in my thinking about professional development and accountability, within an action research self-study of practice as a civil servant, in the context of participation on the Doctor in Education (Leadership) programme at Dublin City University (DCU) in the period 2008-2012. It is at the intersection of these subject positions, between theory and practice, that professional development was explored through the 'leadership problem' of encouraging trainer colleagues to investigate the educational potential of information and communications technologies (ICT) for the development of their practice. Ultimately, this constituted a critical space for sustained dialogue between the self and the social in exploring professional subjectivity. The resources discussed supported the interrogation of social, cultural and historical conditions influencing self-understanding and narrative reasoning (Tamboukou, 2008) and movement from strategic to communicative reasoning (Habermas, 1984). It is claimed that this has significance for the development of a more educational training practice, which expresses a concern for subjectivity and agency in the face of a growing 'performativity' in professional life (Ball, 2003).
\end{abstract}

Keywords: Accountability; e-learning; leadership; professional development; training

\footnotetext{
*Corresponding author: Yvonne Emmett, yvonne.emmett2@mail. dcu.ie
}

\section{Introduction}

\begin{abstract}
... we can say that someone has learned something not when she is able to copy and reproduce what already existed but when she responds to what is unfamiliar, what is different, what challenges, irritates or even disturbs. Here learning becomes a creation or an invention, a process of bringing something new into the world: one's own unique response (Biesta, 2006, p.68).
\end{abstract}

This is an account of professional learning as singular response, of 'responding responsibly' - through action research self-study of training practice - to being called into question by what has challenged and disturbed (Biesta, 2003, 2006) in the endeavour to integrate higher education studies with workplace practice and generate educational knowledge. These challenges have included the ideas that action research self-study must involve reflexive and dialectical critique with regard to one's current position and mode of thinking (McNiff and Whitehead, 2009) and that all acts of knowing are charged with personal commitments that arise from one's experiences (Polanyi, 1958/1974). The context of the selfstudy is my professional development as a civil servant between 2008 and 2012 as I undertook doctoral studies; however, this is a research narrative in media res "when many things have already taken place to make me and my story possible in language" (Butler, 2005, p.39). The basis of ethical practice is located in the critique of the social and political conditions through which this professional, account-able 'I' has emerged (ibid.), critique which has had particular significance for the theory of professional development generated. This has indicated a move from conceptualising professional development as an individual process of acquiring a 'body of knowledge' and skills through recognising the extra-individual - the cultural-discursive, social and material-economic - dimensions (Kemmis, 2010), to exploring a psycho-social understanding (Hollway and Jefferson, 2000; Oliver, 2002). In this move, it has become possible to 'see' the psychic effects 
of power relations (Butler, 1997) and how these moderate what learning can (or cannot) happen in the workplace (Vince, 2001). Such knowledge has implications for the development of a more educational training practice.

I begin by outlining the context for my self-study of professional development, an 'object of investigation' already made within a set of discourses contributing vocabulary, concepts and pre-understandings (Usher, 1993). Next, I reflect on the problem of 'learning from experience', which required new interpretive resources (ibid.) to get behind the objective façade of public service reforms. These are not just 'out there' in structures or procedures, but enter into us through the policy technology of 'performativity' to produce a new kind of professional subject for whom struggles with control over judgement and values are individualised, and often internalised (Ball, 2003). These interpretive resources are explored through attention to the issue of accountability, which emerged as a significant ontological problem for the research: a problem that re-surfaced in the struggle to write this account, and which I explore here in terms of its relationship to subjectivity and agency. Finally, I explore the implications of these ideas for developing a more educational training practice.

\section{Professional Development: Re-forming the Subject}

Influenced by Bourdieu's $(1977,1990)$ concept of habitus as one's positioning or learned disposition to act, which emerges through relation to the social conditions one moves through, my self-study (Emmett 2013) included the attempt to understand my own habitus and the field within and against which I have been professionally formed. It reflected on the trajectory of my professional development over a twenty-year career in the Irish Civil Service, including my role as Training Officer in the Office of the Revenue Commissioners between 2004 and 2009. This was set against the ground of rolling 'public service reform' initiatives, beginning with the launch of Strategic Management Initiative (SMI) in 1994, and the publication of Delivering Better Government (DBG) in 1996 (Department of An Taoiseach, 1996), which would challenge the traditional 'policy technologies' of professionalism and bureaucracy, and introduce, in time, a new 'technology of performativity' (Ball, 2003). Influenced by so-called 'New Public Management' (Hood, 1995) reforms elsewhere, these presented 'strategic management', 'human resource management' (HRM) and 'performance-based accountability' as solutions to the problem of 'public service modernisation', for which a Co-ordinating Group of Secretaries-General of Government Departments would provide the 'transformational leadership'. They became enacted through a range of new material practices, in particular the introduction of the Performance Management and Development System (PMDS) in 2000, to create cascading layers of measures and targets to link the individual to supposed unitary organisational strategies and objectives, and to visibilise his/her contribution (Townley, 2002b). This was not just reform of organisations, but of subjectivities, requiring us each to take a new relationship to ourselves, our practices and each other; to be judges of our own and each other's performance - to be calculating (Ball, 2003). And, training and development was viewed instrumentally as a tool for helping to 'deliver' this change. The DBG recommended that in order to support the programme of reforms set out in SMI, departments/offices should increase their spending on training and development from a (then) average of $0.75 \%$ of payroll to $3 \%$ - later increased to $4 \%$. However, as Power (1997, p.9) reminds us: "programmatic [or normative] expectations may be created in excess of those that it can really satisfy", generating an 'expectations gap' which must additionally be managed and following a review by the Comptroller and Auditor General (2000) disciplinary power was exerted on training practice across the civil service to account for itself through evaluation, "to provide evidence of an increase in the level of the performance of the public service" (Civil Service Training and Development Centre, 2011, p.2), and to prove 'value for money' through subscription to an evaluation model that assumes a causal chain of impact between training, individual performance, organisational results, and a 'return on investment'. Critically, this model, which has been naturalised, reinforces a view of training as transmission (Vanderstraeten and Biesta, 2006) and learning as individual cognitive acquisition (Hodkinson et al, 2008). Alongside PMDS it serves to 'couple' the tasks and routines of training personnel more tightly to the programmatic ideas and values which shape training's mission and legitimate its performance - the managerial desire to shape employee behaviours and increase productivity, circumscribing trainers' legitimate interests to debate about the efficiency or effectiveness of particular methods in meeting 'business objectives'.

These, then, were the grounds for my professional development as a Training Officer as I enrolled in the e-learning stream of the M.Sc. in Education and Training programme at DCU during 2005-2007 in order to 'improve 
my performance'. This I see as beginning the sort of learning process that Mezirow (1991) refers to as 'perspective transformation'. Here, teaching embodied the concept of curriculum as praxis, being underpinned by an action research approach that articulated a view of each - students and lecturers - as practitioner-researchers, co-learners in dialogic collaborative enquiry into our pedagogical practice, including the educational values sustaining our teaching and learning, and the development of e-learning artefacts to support and improve that practice. As a result of this distinctive teaching approach (see Farren, 2009), I came to realise the singular context in which each person's learning occurs, informed by a unique biography of experiences and relationships. I came to see learning, not as acquisition (Biesta, 2006) but as dialogic and collaborative, and to value the potential that new forms of ICT offer to improve access to training and development. The aim was to make it more educational in the sense of increasing opportunities for dialogue, collaboration and critical reflection on what we are doing in organisational life and why we are doing it. This was the object of action in my action research self-study of professional development - influencing the use of ICT for dialogic collaborative learning (Farren, 2005), while the object of knowledge lay in clarifying the nature of e-learning as an educational leadership issue. Here, I was thinking of my professional development in terms of learning 'how to provide leadership' in order to influence the former objective, reflecting an 'ingenuous curiosity' (Freire, 1998) with regard to the concept of educational leadership as the subject of doctoral studies; and a substantionalist ontology (Emirbayer, 1997), assuming leadership as personal capacity (Gronn, 2009), and professional development as individual acquisition of knowledge and skills. This identification with the leadership signifier was doubtless influenced by the publication earlier that year of a much-heralded review of the Irish Public Service by the OECD (2008) which articulated the signifiers 'leadership' (84 instances), 'accountability' (124 instances), and 'performance' (945 instances) into a chain of meaning (Laclau and Mouffe, 1985/2001) to enjoin the public service manager - like me - to position themselves within, and become committed to, the 'public service reform' discourse, to incorporate it into narratives of self-identity and to develop a leadership self-image congruent with reform objectives (Alvesson and Willmott, 2002). The leadership identity is potent because it has positive cultural valence and can be a source of greater self-esteem, significance and affirmation than a managerial one (Carroll et al, 2008). But this would be a 'failed identification' for I was to encounter a traumatic sense of failure to live up to the normative leadership model expressed in competency frameworks and other discursive resources (see for example, Alverez-Antolinez et al, 2007; Wallis and McLoughlin, 2007; Cawley and McNamara, 2008; Garavan et al, 2009; Boyle and MacCarthaigh, 2011; McCarthy et al, 2011), in an ongoing struggle to communicate the dialogical collaborative understanding of e-learning developed in the higher education context in the face of its reification (Berger and Luckmann, 1996/1991) by training personnel as 'electronic delivery of content'; 'something' less effective than face-to-face training, with the potential to disrupt established training practice and threaten 'accomplished' trainer identity and role security. And it was in this space of emotional remainder, of a 'deficit view' of myself, and of difficulty in narratively analysing this experience in order to learn from it, that the theoretical resources discussed in the next section made it possible to reveal some of the psychic and affective forces that such signifiers cover over (Lapping, 2011). These showed the way to deconstructing the texts of my professional formation, and ultimately to recovering agency and meaning by making it possible to re-consider the 'educational leadership problem' in terms of the axiological conflict between the educational values underlying the dialogic collaborative understanding and the programmatic values authorising training as an organisational practice; in terms of the conceptual conflict between thinking communication (and training) as the sharing and interpretation of meaning and thinking it as transmission of information; and in terms of politics, which is to say the power relations embedded in hierarchy, and how such value conflicts are mediated, as well as how organisational resources are distributed.

\section{Accountability for movement towards a more educational training practice}

My research account emerged from a narrative analysis (Polkinghorne, 1995) of my professional development to tell the story of how I took action to improve my capacity to support training colleagues to explore the educational potential of ICT for their practice by improving my own learning. It shows how I hold myself accountable for working systematically towards resolving the ontological contradiction between valuing the possibilities that new forms of ICT present for enacting a more dialogical form of training and experiencing its negation in my workplace. It also shows why such account-ability can't be taken for granted, for the experience it narrates includes 
depression in the face of a sense of failure to live up to a normative 'leadership ideal' that exaggerates individual agency (Gronn, 2010), emphasising entrepreneuralism and a capacity to influence beyond authority. And it includes, in consequence, feelings of shame and a 'failure of language' - the inability to symbolise affect, the capacity of which is central to learning from experience (Bion, 1962/1984), indeed to subjectivity (Oliver, 2002).

It was here in a state of not-knowing, of a circling desire to make meaning of the emotional experience - the 'epistemophilic instinct' (Klein, 1930) - and the impossibility of representation that the "hyperactivity with signifiers", which Kristeva (1989, p.59) notes can paradoxically attend such 'asymbolia', manifested in play on the word accountability, and then on its double-meaning: the first in the sense just articulated as account-ability, the ability to narrate one's experience - a fundamental structure of human experience (Connelly and Clandinin, 1990) and reasoning (Bruner, 1985, 1991); and the second in the political sense of being held to account by others, in particular, to how this abstract principle is rendered technically (Charlton, 2002) and the power relations it engenders. And it was here, in the tension between both meanings that I began to explore its relationship to subjectivity and agency through Foucault's ideas about disciplinary power as developed by Townley (1994) and Rose and Miller (1992), and then through Oliver's (2002) concept of social melancholy, which extends Kristeva (1989).

This was the emergence of thinking as a developmental apparatus to cope with thoughts that arose from raw experience and the energy of affects, thoughts that were initially too difficult to think because they presented a threat to self-identity (Bion, 1962/1984); and a challenge to the idea of learning from experience as the outcome of a cognitive-analytical process, that the meaning of events might be set by their chronological order (Pitt and Britzman, 2003). By tolerating frustration, and staying in contact with the work, it gradually became possible to work out what it needed, and I could move from striving to maintain self-image (Safán-Gerard, 2002) towards identification with my actions and their consequences for others, and a radical taking of responsibility that is possible when agency is not so absorbed in identity work (Roberts, 2005). This was also the process of working through 'trauma', in the sense of unassimilated experience (Caruth, 1996), in order to recover language, meaning, subjectivity and agency, even while narration recalled the trauma (Oliver, 2004).

In the first move, discovering Michel Foucault's scholarship, and its address to the triangle of power, knowledge and subjectivity, helped me to see my attachment to a leadership identity, my investment in leadership discourse (Hollway and Jefferson, 2000) as an effect of power-knowledge practices, and to see the desirability of identifying the discourses and technologies shaping my own (and my training colleagues) understandings and the tasks and routines of our professional practice.

Central to Foucault's method is the production of genealogies, or histories, of social practices and their effects on subjectivity. Here the aim is to identify the conditions of their possibility, to trace the role of power-knowledge relations in their emergence, and, in revealing their historical contingency, to show the possibilities for thinking and acting otherwise (Foucault, 1988). For Foucault, such investigations constitute exercises in the "critical ontology of ourselves and our present”(1984, p.50),

in which the critique of what we are is at one and the same time the historical analysis of the limits that are imposed on us (ibid.).

The hybrid 'power-knowledge' is used to underline their intimate relation: relations of power cannot be established without knowledge of subjects and the production of 'truths'; and power relations shape knowledge production, influencing what can be known, through a politics of preferred knowledge and knowers (Gunter, 2001). As Foucault, puts it:

We are subjected to the production of truth through power and we cannot exercise power except through the production of truth (Foucault, 1980, p.93).

For me, this pointed to the role of power relations in the production of leadership knowledge, and suggested the value of undertaking a rudimentary genealogical analysis with a view to understanding why I had reproduced a particular concept of leadership within my original research proposal. This suggested it was something I could learn 'to provide', reflecting an instrumental or strategic rationality rather than a communicative one (Habermas, 1984), and what the effects of such a concept were, in particular, the effects on (my) professional subjectivity (see Emmett 2013, pp.119-129).

In turn, this led me to Barbara Townley's work, which applies Foucault's concepts to analysis of management practices, and in particular it led me to her genealogy of HRM, which makes visible its operation as "a discourse and technology of power" (Townley, 1994, p.138) that relies on the biologically-oriented personnel/ organisational psychology (Steffy and Grimes, 1992) to produce and legitimate a matrix of techniques that can locate the individual as unit of production. This, read alongside her work 
on performance measurement (Townley, 1996; Townley et al, 2003) and strategic performance management systems (Townley, 2001, 2002a, 2002b), raised significant questions for me about the role of HRM techniques in reconstructing accountability within the Irish public service since the launch of SMI in 1984, and in shaping understanding of what it means to be accountable (Townley, 1996) as a civil servant. It helped me to locate so-called 'performance-based accountability' (Embleton, 1997) as part of the wider neoliberal discourse (Harvey, 2005), in particular its address to 'reform' of public administrations - what Hood (1995) coined New Public Management. It helped me to see how PMDS introduced in 2000 as part of SMI works to produce a calculable and accountable subject (Townley, 1996), knowable in particular ways, rankable within the organisation, and amenable to interventions that will make her more self-disciplining. This is effected, in part, through the use of the competency framework (see Centre for Management and Organisation Development, 2002), a taxonomic form of knowledge that exercises power by inscribing behaviours that are desirable in employees and using this knowledge as the basis for recruitment and selection, appraisal, and training and development (Townley, 1994; Finch-Lees et al, 2005; Carroll et al, 2008); and the performance appraisal, which constitutes an examinational and confessional practice in which the employee participates in an assessment of the self in relation to these norms (Finch-Lees et al, 2005) and the performance targets she is assigned. This serves to classify and order the employee (Townley, 1994) through an annual rating of her 'performance' on a five-point rating scale, and produces a distinction between the 'performer' and 'underperformer', who is to be remediated through training, for example, or disciplined (see Department of Public Expenditure and Reform, 2011a, 2011b) .

This relationship between power, knowledge and subjectivity was further clarified for me, after reading Rose and Miller's (1992) analysis of the emergence of welfarism using the Foucauldian concept of 'governmentality' (governmental rationality), when I attempted another genealogical sketch, this time in relation to the 'strategy' signifier that is frequently co-present with 'leadership' in 'public service reform' discourse, and followed their example to analyse SMI as an instance of governmentality (see Emmett 2013, pp.172-183).

Taken together these analyses pointed to the use of accountability as a discursive resource within the 'public service reform' process to rationalise the implementation of performance measurement and management techniques, with the aim that these should produce a particular type of subjectivity and subject - an employee who would incorporate power's aims over his/her thinking and behaviour, seeing them as 'natural' and consistent with self-interest. Here, Townley (1996, p.571) says, accountability functions as a discipline

imposing an order on a series of events and act[ing] on the individual to give both a sense of identity and to construct what it is to be accountable.

It objectivises individuals, making them objects of knowledge and "thereby able to be managed, in a particular way" (ibid., p.569) and it subjectivises them, presenting them

with an image of themselves, an identity which then becomes the basis of their self-knowledge .... [and] the basis for individuals to modify or change their behaviour (ibid.)

In the second move, discovering Kelly Oliver's work, which explores how oppression and domination operate through culture to 'colonise psychic space' (Oliver, 2004), suggested a bridge towards understanding how the objectifying operations of 'performance management' that Townley describes might manifest psychically, and from there to 'working through' personal experience and then drawing out the implications for enacting a more educational training practice and conceptualising e-learning as an educational leadership issue.

Drawing on psychoanalytic theory, she diagnoses 'social melancholy' as the result of social and cultural conditions that "constitute the depressed subject as ashamed and lacking agency" (Oliver, 2005, p.100), conditions that are covered over when depression is pathologised as an individual problem. She characterises it as "the internalisation of the loss of a loved or lovable self-image" (ibid., p.101) arising from a lack of "positive self-significations" (ibid., p.105) available within a dominant culture that privileges certain values, identities and experiences while abjecting others, and an absence of space or support for sublimation, that is, the discharge of bodily drives and affects into social meaning through language and other forms of signification, especially affect arising from this lack.

In 'Social Melancholy, Shame and Sublimation' (2005), for example, she discusses how the prevalence of female depression may be understood in terms of a patriarchal culture that debases girls and women, devaluing their experiences and offering only denigrated self-images, while rendering their emotional expression a sign of inferiority. Elsewhere, she writes that this is about thinking through the "inequities in access to psychic resources ... that accompany inequities in the distribution of economic resources" (Oliver, 2008, p.3). She is clear that we can 
have no sense of ourselves as subjects with any identity apart from our relations with others, and that dominant cultures shore up privilege through privileging access to positive identifications and the possibility of sublimation. Without sublimation, she says, idealisation is impossible and without idealisation we can neither conceptualise our experience nor set goals for ourselves, that is, without idealisation we cannot resist domination (Oliver, 2004).

While her work deals with extremes of objectification, read with Foucault's work on power-knowledge it underlines the circumscription of instrumental values and strategising identities by the discourse of 'performance-based accountability'; the restriction of social space for alternative meaning-making arising from practices that enact a more competitive, individualistic employment relationship; and the colonisation of psychic space through the incorporation of a performative super-ego that turns idealisation into notions of performance and under-performance, corrupting the process of sublimation and undermining access to meaning (Oliver, 2005). It underlines the experience that when one cannot positively locate oneself and one's experience within available cultural meaning and there is no supportive space for discharging and symbolising affect, one is left identifying with the abject, with failure. This signals an affective break in social bonds, a loss of the idea of oneself as loved and lovable, giving rise to feelings of shame directed at one's own being and to a loss of faith in words - manifesting in the asymbolia that Kristeva (1989) identifies with the depressive position.

This was my own experience of failed identification with a normative leadership ideal that represented the incorporation of restrictive meaning; of a lack of cultural valuation for the educational and communicative (non-strategic); and of the absence of social space for symbolising this conflict, which left me stuck in the body and struggling to account for my own experience. In other words, after Oliver, one could say that 'performance-based accountability' damaged my subjectivity and agency through undermining the possibility for idealisation and sublimation - for the movement from the body to social meaning. For me, this underlines the paradox at the heart of the experience of 'performance-based accountability': it can damage subjectivity and agency through damaging the subject's ability to account (to herself) for her own objectification, which ability is at the same time the very basis for recovering subjectivity and agency through what Kristeva (2002) terms an 'intimate revolt'; that is, through questioning the past, 'law', tradition, and authority - the 'normalising order' - as the basis for sustaining an open psychic space (Oliver, 2002). And it underlines the value of an action research self-study approach to researching professional development, which alongside critical management studies, has ultimately provided the accepting social support and meaning for questioning the managerialist framing of e-learning and the transformation of depression into educational knowledge.

We can say this differently, following Oliver's (2001) work on 'witnessing', in a way that can help us to draw out the ethical implications for training: that 'performance-based accountability' can damage the inner witness that must be in place "in order to think, talk and act as an agent" (ibid., p.87), which in turn depends on the possibility of address to another. If the subject is, as she puts it, "the result of a response to an address from another and the possibility of addressing itself to another" (ibid., p.105), then our ethical obligation is to respond to others in ways that open up rather than close off the possibility of response. 'Performance-based accountability' can undermine subjectivity by compromising address-ability and response-ability, but a more educational training practice can help to restore it if it can challenge its own instrumentalism, adopt a more dialogic stance (see Table 1), and provide social space and affective support for questioning and meaning-making. This underlines the axiological nature of e-learning as an educational leadership issue: the challenge to communicate a dialogic collaborative understanding of e-learning, which is at odds with the programmatic values authorising and directing training practice, and with translating ideas from the higher education context for the public service workplace dominated by strategic reason.

\section{Conclusion}

This was 'difficult knowledge' that threatened the ego's boundaries (Britzman, 1998, 2000) and challenged the idea of learning from experience as a primarily intellectual endeavour (Boud and Walker, 1998). Ultimately, the writers discussed above provided social support for symbolisation that depended on transforming the "uncritically assimilated meaning perspectives" (Mezirow, 1991, p.4) that constituted my frame for interpreting experience. The implications of this transformation in thinking for the development of a more educational training practice are significant and begin with a psycho-social understanding of professional development. In the context of the training relationship, this entails political attention to current discourses and practices shaping professional subjectivity, as well as to the subject positions, relations and understandings these engender. The critique of these can inform 
Table 1: Constructing the poles of the monologic-dialogic continuum of training practice (after Stewart and Zediker, 2000)

\begin{tabular}{lll}
\hline & Monologic & Dialogic \\
\hline Aim/purpose & $\begin{array}{l}\text { To transmit certain values and meanings as } \\
\text { authoritative }\end{array}$ & $\begin{array}{l}\text { To support critical thinking and intersubjective } \\
\text { understanding }\end{array}$ \\
Knowledge & $\begin{array}{l}\text { Fixed; separate from people; a commodity that can } \\
\text { be transmitted and acquired - not altered by the } \\
\text { encounter }\end{array}$ & $\begin{array}{l}\text { Contingent socio-cultural meaning-making; open to } \\
\text { re-interpretation in the light of new interpretive frames, } \\
\text { which may arise out of the encounter itself }\end{array}$ \\
& $\begin{array}{l}\text { 'Expert' who transmits knowledge to 'less } \\
\text { knowledgeable' trainees but is not herself educated by } \\
\text { the encounter; her 'knowledge-base' remains unaltered }\end{array}$ & $\begin{array}{l}\text { Co-learner who brings different experiences and } \\
\text { meanings and is open to being educated by the } \\
\text { encounter and the experiences and meanings others } \\
\text { bring }\end{array}$ \\
& $\begin{array}{l}\text { Acquires knowledge transmitted by trainer but is not } \\
\text { involved in knowledge creation }\end{array}$ & $\begin{array}{l}\text { Brings personal knowledge to bear in co-constructing } \\
\text { new knowledge through the encounter }\end{array}$ \\
Curriculum & $\begin{array}{l}\text { Content is 'univocal', presenting a single interpretive } \\
\text { frame }\end{array}$ & $\begin{array}{l}\text { Content is multivocal, contemplating multiple } \\
\text { interpretive frames }\end{array}$ \\
& $\begin{array}{l}\text { Serve as transmission or monologic devices: 'the } \\
\text { meaning is in the text' }\end{array}$ & $\begin{array}{l}\text { Serve as resources to thinking: meaning is constructed } \\
\text { 'intertextually' and intersubjectively }\end{array}$ \\
\hline
\end{tabular}

a curriculum that is less 'process' or 'product'; which is to say, less concerned with transmission of content or achieving behavioural objectives, and more 'process' and 'praxis'; which is to say, more concerned with unfolding interaction and subjectivity (Smith, 1996, 2000). It also entails awareness that emotional investment in any discursive position will be mediated by biographical histories of recursive positioning in discursive and material realities, including potentially conflicting positions; and that as anxiety/desire in relation to our worker identities and security infuses our positioning, some thoughts may initially be 'too difficult to think'. This is especially salient in the context of an economic 'austerity' and a renewed programme of 'public service reform' (Department of Public Expenditure and Reform, 2011c). It also requires that, as trainers, we learn to pay attention to our emotional investments in subject positions (Holloway, 2011), and suggests the value of learning about the dynamics of emotions as they interact with organisational politics. It also suggests that the effectiveness (or otherwise) of a more educational training practice in supporting participants to challenge their subjection and bring their own subjectivity and values to bear - in other words, 'to intervene in the curriculum' - will depend, not alone on the articulation of educational values, but on the creation of adequately accepting and supportive social spaces; spaces in which difficult experiences and feelings can be interpreted and made meaningful, and which offer positive social valuations that can counter disciplined identifications. This seems especially significant in a context in which e-learning is encountered as a disruption to established training practice, disciplined through PMDS, and potentially threatening to 'accomplished' trainer identity and role security.

\section{References}

[1] Emmett, Y. (2013). How do I create a living theory of leadership development for e-learning as an explanation of educational influence in improving training practice? (Ed.D. thesis, Dublin City University, Ireland). http://doras.dcu.ie/17723/1/Yvonne_ Emmett_Dissertation_11_January_2013.pdf (Accessed 1 January 2014)

[2] Alverez-Antolinez, C., Brennan, D., McKenna, L., Mullen, M., O’Driscoll, A., O’Reilly, P., Rice, N., Sheridan, M., Smyth, G., Smyth, T. \& Usher, N. (2007). Leadership, Structures and Accountability in the Public Service: Priorities for the Next Phase of Reform. Dublin, Ireland: Institute of Public Administration

[3] Alvesson, M. \& Willmott, H. (2002). Identity Regulation as Organizational Control: Producing the Appropriate Individual. Journal of Management Studies, 39(5), 619-644

[4] Ball, S. (2003). The teacher's soul and the terrors of performativity. Journal of Education Policy, 18(2), 215-228

[5] Berger, P.L. \& Luckmann, T. (1991). The social construction of reality: a treatise in the sociology of knowledge. Reprint, London, UK: Penguin Books. (Original work published 1966)

[6] Biesta, G. (2003). Learning From Levinas: A Response. Studies in Philosophy and Education, 22, 61-68

[7] Biesta, G.J.J. (2006). Beyond Learning: Democratic Education for a Human Future. Boulder, USA: Paradigm

[8] Bion, W.R. (1984). Learning From Experience. Reprint, London, UK: Karnac Books. (Original work published 1962) 
[9] Boud, D. \& Walker, D. (1998). Promoting reflection in professional courses: The challenge of context. Studies in Higher Education, 23(2), 191-206

[10] Bourdieu, P. (1977). Outline of a Theory of Practice. Cambridge, UK: Cambridge University Press

[11] Bourdieu, P. (1990). The Logic of Practice. Stanford, USA: Stanford University Press

[12] Boyle, R. \& MacCarthaigh, M. (2011). Fit for Purpose? Challenges for Irish Public Administration and Priorities for Public Service Reform. Research Paper 4, State of the Public Services Series. Dublin, Ireland: Institute of Public Administration http://www.ipa.ie/pdf/Fit_For_Purpose_New_Report. pdf (Accessed 22 March 2012)

[13] Britzman, D.P. (1998). Lost Subjects, Contested Objects: Towards a Psychoanalytic Inquiry of Learning. Albany, USA: State University of New York

[14] Britzman, D.P. (2000). If the Story Cannot End: Deferred Action, Ambivalence and Difficult Knowledge. In Simon, R.J., Rosenberg, S., Eppert, C. (Eds.) Between Hope and Despair: Pedagogy and the Remembrance of Historical Trauma (pp.27-57). Oxford, UK: Rowman and Littlefield Publishers

[15] Bruner, J. (1985). Actual minds, possible worlds. Cambridge, USA: Harvard University Press

[16] Bruner, J. (1991). The Narrative Construction of Reality. Critical Inquiry, 18(1), 1-21

[17] Butler, J. (1997). The Psychic Life of Power: Theories in Subjection. Stanford, USA: Stanford University Press.

[18] Butler, J. (2005). Giving an Account of Oneself. New York, USA: Fordham University Press.

[19] Carroll, B., Levy, L. \& Richmond, D. (2008). Leadership as Practice: Challenging the Competency Paradigm. Leadership, 4(4), 363-379.

[20] Caruth, C. (1996). Unclaimed Experience: Trauma, Narrative and History. Baltimore, USA: Johns Hopkins University Press.

[21] Cawley, B. \& McNamara, T. (2008). Leadership in the Public Service. Administration, 56(3), 1-10.

[22] Centre for Management and Organisation Development. (2002). A Guide to Competency Development in the Civil Service. Dublin: Department of Finance. http://www.finance. gov.ie/documents/smi/cmod_report.pdf (Accessed 22 March 2012).

[23] Charlton, B.G. (2002). Audit, Accountability, Quality and All That: The Growth of Managerial Technologies in UK Universities. In S. Prickett \& P. Erskine-Hill (Eds.), Education! Education! Education! Managerial Ethics and the Law of Unintended Consequences (pp.13-28). Exeter, UK: Imprint Academic.

[24] Civil Service Training and Development Centre. (2011). Learning and Development Framework for the Civil Service 2011-2014. http://hr.per.gov.ie/files/2011/04/Learning-and-DevelopmentFramework.pdf (Accessed 22 March 2012)

[25] Comptroller and Auditor General. (2000). VFM Report 38: Training and Development in the Civil Service. http://www. audgen.gov.ie/documents/vfmreports/TrainDev.pdf (Accessed 22 March 2012)

[26] Connelly, F.M. \& Clandinin, D.J. (1990). Stories of Experience and Narrative Inquiry. Educational Researcher, 19(5), 2-14.

[27] Department of An Taoiseach. (1996). Delivering Better Government: Second Report to Government of the Co-ordinating Group of Secretaries - A Programme of Change for the Irish Civil Service. http://per.gov.ie/wp-content/ uploads/Delivering_Better_Government.pdf (Accessed 22 March 2012)

[28] Department of Public Expenditure and Reform. (2011a). Performance Management and Development System 2012: Guidelines for the Completion of the New PMDS Form. http:// per.gov.ie/wpcontent/uploads/Guidelines-25.11.11.pdf (Accessed 22 March 2012)

[29] Department of Public Expenditure and Reform. (2011b). Guidelines for Managing Underperformance in the Civil Service. http://hr.per.gov.ie/files/2011/04/GuidelinesManaging-Underperformance-in-Civil-Service1.pdf (Accessed 29 June 2012)

[30] Department of Public Expenditure and Reform. (2011c). Public Service Reform Plan. http://per.gov.ie/wp-content/uploads/ Public-Service-Reform-181120112.pdf (Accessed 22 March 2012)

[31] Embleton E. (1997). Issues and Perspectives on PerformanceBased Accountability in the Irish Public Service. Paris, France: OECD, Public Management Service.

[32] Emirbayer, M. (1997). Manifesto for a Relational Sociology. The American Journal of Sociology, 103(2), 281-317.

[33] Farren, M. (2005). How can I create a pedagogy of the unique through a web of betweeness? (Ph.D. thesis, University of Bath, UK). http://www.actionresearch.net/farren.shtml. (Accessed 1 January 2014)

[34] Farren, M. (2009). Co-creating an educational space. Educational Journal of Living Theories, 1(1), 50-68. http:// www.ejolts.net/files/Farren1\%281\%29.pdf (Accessed 1 January 2014).

[35] Finch-Lees, T., Mabey, C. \& Liefooghe, A. (2005). 'In the name of capability': a critical discursive evaluation of competencybased management development. Human Relations, 58(9), $1185-1222$

[36] Foucault, M. (1980). Power/Knowledge: Selected Interviews and Other Writings 1972-1977, edited by Colin Gordon. London, UK: Harvester.

[37] Foucault, M. (1984). What is Enlightenment? In P. Rabinow (Ed.), The Foucault Reader (pp. 32-50). New York, USA: Pantheon Books.

[38] Foucault, M. (1988). The History of Sexuality, Vol. 2: The Use of Pleasure. London, UK: Penguin.

[39] Freire, P. (1998). Pedagogy of Freedom: Ethics, Democracy and Civic Courage. Oxford, UK: Rowman \& Littlefield Publishers.

[40] Garavan, T.N., Hogan, C. \& Cahir-O’Donnell, A. (2009). Developing Managers and Leaders: Perspectives, Debates and Practices in Ireland. Dublin, Ireland: Gill \& Macmillan.

[41] Gronn, P. (2009). 'Hybrid Leader ship’. In Leithwood, K., Mascall, B. and Strauss, T. (eds.) Distributed Leadership According to the Evidence (pp.17-40). NewYork, USA: Routledge.

[42] Gronn, P. (2010). Leadership: its genealogy, configuration and trajectory. Journal of Educational Administration and History, 42(4), 405-435

[43] Gunter, H.M. (2001). Leaders and Leadership in Education. London, UK: Sage

[44] Habermas, J. (1984). The Theory of Communicative Action. Vol. 1: Reason and the Rationalization of Society, trans. T. McCarthy. Boston, USA: Beacon Press

[45] Harvey, D. (2005). A Brief History of Neoliberalism. Oxford, UK: Oxford University Press 
[46] Hodkinson, P., Biesta, G. \& James, D. (2008). Understanding Learning Culturally: Overcoming the Dualism Between Social and Individual Views of Learning. Vocations and Learning, 1(1), 27-47

[47] Hollway, W. \& Jefferson, T. (2000). Doing Qualitative Research Differently: Free Association Narrative and the Interview Method. London, UK: Sage

[48] Hollway, W. (2011). Through discursive psychology to a psychosocial Approach. In Bozatis, N. and Dragonas, T. (eds.) Social psychology: the turn to Discourse (pp.209-240). Athens, Greece: Metaixmio

[49] Hood, C. (1995). The 'New Public Management' in the 1980s: Variations on a Theme. Accounting, Organizations and Society, 20(2/3), 93-109

[50] Kemmis, S. (2010). What is Professional Practice? Recognising and Respecting Diversity in Understandings of Practice. In C. Kanes (Ed.), Elaborating Professionalism: Studies in Practice and Theory (pp.139-166). London, UK: Springer

[51] Klein, M. (1930). The Importance of Symbol Formation in the Development of the Ego. The International Journal of Psychoanalysis, 11, 24-39

[52] Kristeva, J. (1989). Black Sun: Depression and Melancholia. New York, USA: Columbia University Press

[53] Kristeva, J. (2002). Intimate Revolt. The Power and Limits of Psychoanalysis Vol. II., Trans. Jeanine Herman. New York, USA: Columbia University Press

[54] Laclau, E. \& Mouffe, C. (2001). Hegemony and Socialist Strategy: Towards a Radical Democratic Politics. Reprint, London, UK: Verso. (Original work published 1985)

[55] Lapping, C. (2011). Psychoanalysis in Social Research: Shifting theories and reframing concepts. London, UK: Routledge

[56] McCarthy, A., Grady, G. \& Dooley, G. (2011). Leadership in the Irish Civil Service: A $360^{\circ}$ Review of Senior Management Capability. Galway, Ireland: Centre for Innovation and Structural Change (CISC), National University of Ireland Galway. http:// www.nuigalway.ie/cisc/documents/leadership_in_the_irish_ civil_service.pdf (Accessed 21 February 2012)

[57] McNiff, J. \& Whitehead, J. (2009). Doing and Writing Action Research. London, UK: Sage

[58] Mezirow, J. (1991). Transformative Dimensions of Adult Learning. San Francisco, USA: Jossey-Bass

[59] OECD. (2008). Ireland: Towards an Integrated Public Service. Paris, France: OECD. http://per.gov.ie/wp-content/uploads/ Ireland_-_Towards_an_Integrated_Public_Service.pdf (Accessed 22 March 2010)

[60] Oliver, K. (2001). Witnessing: Beyond Recognition. Minneapolis, USA: University of Minnesota Press

[61] Oliver, K. (2002). Psychic Space and Social Melancholy. In K. Oliver and S. Edwin (Eds.), Between the Psyche and the Social: Psychoanalytic Social Theory (pp.49-65). Oxford, UK: Rowman and Littlefield

[62] Oliver, K. (2004). The Colonization of Psychic Space: A Psychoanalytic Theory of Social Oppression. Minneapolis, USA: University of Minnesota Press

[63] Oliver, K. (2005). Social Melancholy, Shame and Sublimation. In S.M. Meagher \& P. DiQuinzo (Eds.), Women and Children First: Feminism, Rhetoric and Public Policy (pp.99118). Albany, USA: State University of New York

[64] Oliver, K. (2008). Response to Reviews of the Colonization of Psychic Space: Towards a Psychoanalytic Social Theory.
Symposia on Gender, Race and Philosophy, 4 (1). http://web. mit.edu/sgrp/2008/no1/Oliver0108.pdf (Accessed 22 March 2014)

[65] Pitt, A. \& Britzman, D. (2003). Speculations on qualities of difficult knowledge in teaching and learning: an experiment in psychoanalytic research, International Journal of Qualitative Studies in Education, 16(6), 755-776

[66] Polanyi, M. (1974). Personal Knowledge. Reprint, Chicago, USA: University of Chicago Press. (Original work published 1958)

[67] Polkinghorne, D.E. (1995). Narrative configuration in qualitative analysis. In J.A. Hatch \& R. Wisniewski (Eds.) Life History and Narrative (pp.5-24). London, UK: Falmer

[68] Power, M. (1997). The Audit Society: rituals of verification. Oxford: Oxford University Press

[69] Roberts, J. (2005). The Power of the 'Imaginary in Disciplinary Processes. Organization, 12(5), 619-642

[70] Rose, N. \& Miller, P. (1992). Political Power Beyond the State: Problematics of Government. The British Journal of Sociology, 43(2), 173-205

[71] Safán-Gerard, D. (February 2002). On Not Knowing: Discerning the Mental and Emotional Requirements of Creative Work. Paper presented at a special group of the Bion 2002 Conference Los Angeles, CA. http://www.desy.com/ writingsPDFs/on_not_knowing.pdf (Accessed 22 March 2014)

[72] Smith, M. K. (1996, 2000) 'Curriculum theory and practice.' The Encyclopaedia of Informal Education. http://www.infed.org/ biblio/b-curric.htm (Accessed 3 September 2012)

[73] Steffy, B.D. \& Grimes, A.J. (1992). Personnel/Organizational Psychology: A Critique of the Discipline. In M. Alvesson and H. Willmott (Eds.), Critical Management Studies (pp.181-201). London, UK: Sage

[74] Stewart, J. \& Zediker, K. (2000). Dialogue as tensional, ethical practice. Southern Communication Journal, 65(2-3), 224-242

[75] Tamboukou, M. (2008). A Foucauldian Approach to Narratives. In Andrews M., Squire, C. and Tamboukou, M. (Eds.) Doing Narrative Research (pp.102-120). London, UK: Sage

[76] Townley, B. (1994). Reframing Human Resource Management: Power, Ethics and the Subject at Work. London, UK: Sage Publications

[77] Townley, B. (1996). Accounting in Detail: Accounting for Individual Performance. Critical Perspectives on Accounting, 7, 565-584

[78] Townley, B. (2001). The Cult of Modernity. Financial Accountability and Management, 17(4), 303-310

[79] Townley, B. (2002a). The Role of Competing Rationalities in Institutional Change. The Academy of Management Journal, 45(1), 163-179

[80] Townley, B. (2002b). Managing With Modernity. Organization, 9(4), 549-573

[81] Townley, B., Cooper, D.J. \& Oakes, L. (2003). Performance Measures and the Rationalization of Organizations. Organization Studies, 24(7), 1045-1071

[82] Usher, R. (1993). Experiential learning or learning from experience: does it make a difference? In Boud, D., Cohen, R., \& Walker, D. (eds.) Using Experience for Learning (pp.169-180). Buckingham, UK: Open University Press

[83] Vanderstraeten, R. \& Biesta, G. (2006). How is Education Possible? Pragmatism, Communication and the Social Organisation of Education. British Journal of Education Studies, 54(2), 160-174 
[84] Vince, R. (2001). Power and emotion in organizational learning. Human Relations, 54(10), 1325-1351

[85] Wallis, J. \& McLoughlin, L. (2007). A diagnosis of leadership effectiveness in the Irish Public Sector. Public Management Review, 9(3), 327-351 